\title{
Global marine biodiversity in the context of achieving the Aichi Targets: ways forward and addressing data gaps
}

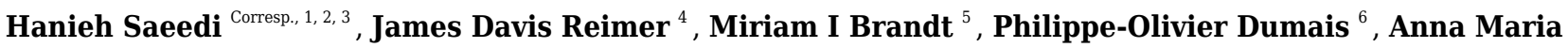 \\ Jażdżewska $^{7}$, Nicholas W Jeffery ${ }^{8}$, Peter M Thielen ${ }^{9}$, Mark John Costello ${ }^{10}$ \\ 1 Senckenberganlage 25, 60325, Senckenberg Research Institute and Natural History Museum, Frankfurt am Main, Germany \\ 2 FB 15 Biological Sciences Institute for Ecology, Diversity and Evolution Biologicum,60439, Goethe University of Frankfurt, Frankfurt am Main, Germany \\ 3 Senckenberg Research Institute and Natural History Museum, Senckenberganlage 25, 60325, OBIS Data Manager, Deep-sea Node, Frankfurt am Main, \\ Germany \\ 4 Marine Invertebrate Systematics \& Ecology Laboratory, Faculty of Science, 1 Senbaru, Nishihar, University of the Ryukyus, Okinawa 903-0213, Japan \\ 5 IMARBEC, fremer, IRD, CNRS, Univ. Montpellier, Sète, France \\ 6 Benthic Ecology Laboratory, Biology Department, Université Laval, Québec, Canada \\ 7 Laboratory of Polar Biology and Oceanobiology, Department of Invertebrate Zoology and Hydrobiology, Faculty of Biology and Environmental Protection, \\ University of Lodz, Lodz, Poland \\ 8 Fisheries and Oceans Canada, Bedford Institute of Oceanography, Dartmouth, Nova Scotia, Canada \\ 9 Research and Exploratory Development Department, Johns Hopkins Applied Physics Laboratory, Laurel, Maryland, United States \\ 10 Institute of Marine Science, University of Auckland, Auckland, New Zealand \\ Corresponding Author: Hanieh Saeedi \\ Email address: hanieh.saeedi@senckenberg.de
}

In 2010, the Conference of the Parties of the Convention on Biological Diversity agreed on the Strategic Plan for Biodiversity 2011-2020 in Aichi Prefecture, Japan. As this plan approaches its end, we discussed whether marine biodiversity and prediction studies were nearing the Aichi Targets during the $4^{\text {th }}$ World Conference on Marine Biodiversity held in Montreal, Canada in June 2018. This article summarises the outcome of a five-day group discussion on how global marine biodiversity studies should be focused further to better understand the patterns of biodiversity. We discussed and reviewed seven fundamental biodiversity priorities related to nine Aichi Targets focusing on global biodiversity discovery and predictions to improve and enhance biodiversity data standards (quantity and quality), tools and techniques, spatial and temporal scale framing, and stewardship and dissemination. We discuss how identifying biodiversity knowledge gaps and promoting efforts have and will reduce such gaps, including via the use of new databases, tools and technology, and how these resources could be improved in the future. The group recognised significant progress toward Target 19 in relation to scientific knowledge, but negligible progress with regard to Targets 6 to 13 which aimed to safeguard and reduce human impacts on biodiversity. 
4

\title{
Global marine biodiversity in the context of achieving the Aichi Targets: ways forward and addressing data gaps
}

\author{
Hanieh Saeedi' ${ }^{1,2,3 *}$,James Davis Reimer,5, Miriam I. Brandt ${ }^{6}$, Philippe-Olivier Dumais ${ }^{7}$, \\ Anna Maria Jażdżewska ${ }^{8}$, Nicholas W. Jeffery ${ }^{9}$, Peter M. Thielen ${ }^{10}$, Mark Johhn Costello ${ }^{11}$ \\ ${ }^{1}$ Senckenberg Research Institute and Natural History Museum, Senckenberganlage 25, 60325 \\ Frankfurt, Germany \\ ${ }^{2}$ Goethe University of Frankfurt, FB 15, Institute for Ecology, Evolution and Diversity, Max- \\ von-Laue-Str. 13, 60439 Frankfurt am Main, Germany \\ ${ }^{3}$ OBIS Data Manager, Deep-sea Node, Senckenberg Research Institute and Natural History \\ Museum, Senckenberganlage 25, 60325 Frankfurt, Germany \\ ${ }^{4}$ Marine Invertebrate Systematics \& Ecology Laboratory, Faculty of Science, University of the \\ Ryukyus, 1 Senbaru, Nishihara, Okinawa 903-0213, Japan \\ ${ }^{5}$ Tropical Biosphere Research Center, University of the Ryukyus, 1 Senbaru, Nishihara, Okinawa \\ 903-0213, Japan \\ ${ }^{6}$ MARBEC, Ifremer, Univ. Montpellier, IRD, CNRS, Sète, France \\ ${ }^{7}$ Benthic Ecology Laboratory, Biology Department, Université Laval, 1045 rue de la Médecine, \\ Ville de Québec, Québec, Canada, G1V 0A6 \\ ${ }^{8}$ Laboratory of Polar Biology and Oceanobiology, Department of Invertebrate Zoology and \\ Hydrobiology, Faculty of Biology and Environmental Protection, University of Lodz, Banacha \\ 12/16 St., 90-237 Lodz, Poland \\ ${ }^{9}$ Bedford Institute of Oceanography, Fisheries and Oceans Canada, Dartmouth, Nova Scotia, \\ Canada, B2Y 4A2 \\ ${ }^{10}$ Research and Exploratory Development Department, Johns Hopkins Applied Physics \\ Laboratory, 11100 Johns Hopkins Road, Laurel MD 20723, United States \\ ${ }^{11}$ Institute of Marine Science, University of Auckland, Auckland 1141, New Zealand
}

Corresponding Author:

Hanieh Saeedi $1^{1,2,3 *}$

Email address: hanieh.saeedi@senckenberg.de 
56

57

58

59

60

61

62

63

64

65

66

67

68

69

70

71

72

73

74

75

76

77

\section{Abstract}

In 2010, the Conference of the Parties of the Convention on Biological Diversity agreed on the Strategic Plan for Biodiversity 2011-2020 in Aichi Prefecture, Japan. As this plan approaches its end, we discussed whether marine biodiversity and prediction studies were nearing the Aichi Targets during the $4^{\text {th }}$ World Conference on Marine Biodiversity held in Montreal, Canada in June 2018. This article summarises the outcome of a five-day group discussion on how global marine biodiversity studies should be focused further to better understand the patterns of biodiversity. We discussed and reviewed seven fundamental biodiversity priorities related to nine Aichi Targets focusing on global biodiversity discovery and predictions to improve and enhance biodiversity data standards (quantity and quality), tools and techniques, spatial and temporal scale framing, and stewardship and dissemination. We discuss how identifying biodiversity knowledge gaps and promoting efforts have and will reduce such gaps, including via the use of new databases, tools and technology, and how these resources could be improved in the future. The group recognised significant progress toward Target 19 in relation to scientific knowledge, but negligible progress with regard to Targets 6 to 13 which aimed to safeguard and reduce human impacts on biodiversity.

\section{Introduction}

The 'Strategic Plan for Biodiversity 2011-2020' of the Convention on Biological Diversity was agreed during the 10th Conference of the Parties, held from 18 to 29 October 2010, in Aichi Prefecture, Japan. The strategic plan included five main "Strategic Goals" that were divided into 20 targets. Each 'Aichi Target' was designed to better understand and predict biodiversity dynamics, such as how biological diversity underpins ecosystem function, and how the provision of ecosystem services is essential for human well-being. Meeting the Aichi Targets would ultimately benefit local livelihoods and economic development, and is essential for biodiversity maintenance and poverty reduction (Shepherd et al. 2016; Tittensor et al. 2010). In this paper, we report on the findings of a working group that discussed how the targets related to marine biodiversity were being achieved.

\section{Survey Methodology}

The 4th World Conference on Marine Biodiversity (WCMB 2018) in Montreal organised a working group to review and evaluate how the Aichi Targets have been met by the global community. In particular, the review group was asked to focus on Target 19 regarding scientific knowledge about biodiversity as this was the area of most expertise of the participants. To identify and reduce biodiversity knowledge gaps we examined how marine biodiversity discoveries and their predictions need to be redirected to better understand and predict how marine biodiversity will change within the next 10 years. Here, we identify seven important priorities for this topic to support the Aichi Targets (Table 1). These foci arose iteratively from discussion between the group 
82

83

84

85

86

87

88

89

90

91

92

93

94

95

96

97

98

99

100

101

102

103

104

105

106

107

108

109

110

111

112

113

114

115

116

117

members and other groups at the conference. The priorities address issues of (1) data standards, (2) education in data management, (3) taxonomic expertise, (4) genetic tools, (5) international collaboration, (6) identifying knowledge gaps and understanding biogeography, and (7) the need to reduce human pressures on marine biodiversity.

\section{Reviewed Priorities}

\section{Results and Discussion}

\section{Developing, improving and enhancing biodiversity data standards, exchange, and analytical tools, via standardized techniques.}

Recent marine biodiversity discoveries have been greatly enhanced by standardised open-access taxonomic and biogeographic data repositories such as the World Register of Marine Species (WoRMS) and the Ocean Biogeographic Information System (OBIS) (Ahyong 2018; Costello et al. 2013a). Large-scale development of marine biodiversity data standards and exchange started when the Census of Marine Life (2000-2010) established OBIS (O'Dor et al. 2012).

Biodiversity data standards, such as "Darwin Core", a data schema that provides stable terms and vocabularies for universal sharing of biodiversity data, and management techniques have been improved to ensure that published data have high quality. For example, there are now available taxonomic and geographic data management tools and R packages, e.g., rOBIS (Provoost P 2018) (Figure 1). The taxon match tool in WoRMS can automatically check the correct spelling, authority, classification and validity of species names uploaded to a webpage (Costello et al. 2013a). A marine gazetteer matches place names to geographic coordinates and polygon (shapefiles) of localities (Claus et al. 2014). The standardization and open storage of metadata, taxonomic, genetic, and geographic data also allows for greater stewardship by stakeholders, enhanced public awareness and education, and importantly, the ability to easily share data among institutions (Figure 1).

Developing biodiversity data standards and data exchange protocols enables both data users and providers to benefit from the high-quality data that later allow for more reliable and precise biodiversity analyses. The expansion of the OBIS data schema to include additional information associated with sampling events, including sampling methods and environmental data, is a significant recent advance (De Pooter et al. 2017). The open-access publication of thousands of data sets integrated into OBIS has enabled major advances in our understanding of global patterns of biodiversity. For example, several studies have utilized open-access marine species distribution records to discover and confirm large-scale biodiversity patterns. These findings include observations that global species richness is bimodal with latitude, and that species richness decreases with depth (Chaudhary et al. 2016a; Chaudhary et al. 2017; Costello \& Chaudhary 2017a; Saeedi et al. 2017a; Saeedi \& Costello 2019a; Saeedi \& Costello 2019b; Saeedi et al. 2017b). We conclude that there has been noticeable progress towards achieving the potential of Aichi Target 19 through establishing global databases and taxonomic resources. These are leading 
118 to better quality control, data management efficiencies, and new insights into our understanding 119 of biodiversity. However, these benefits, as well as contributions to these resources, are not 120 realised in all countries.

121

122

123

124

125

126

127

128

129

130

131

132

133

134

135

136

137

138

139

140

141

142

143

144

145

146

147

148

149

150

151

152

153

154

155

156

157

\section{Educational activities to increase data mobilisation by taxonomists, data users, and/or wider audiences.}

Many scientists and the general public around the world are unaware of the presence and advantages of large-scale open-access databases. Even if scientists are familiar with these facilities, data preparation and submission can be complex for contributors unfamiliar with data publication protocols. These issues are more pronounced for scientists in developing countries or non-native English speakers. As a result of these perceived and real data publication obstacles, significant biodiversity and biogeography knowledge remains in personal databases and nondigital archives. These logistical hurdles and data ownership perceptions frequently stand in the way of data publication. To expose researchers to these resources, initiatives like OceanTeacher Global Academy (OTGA) (https://classroom.oceanteacher.org) or Ocean School (https://oceanschool.nfb.ca/) provide a valuable educational platform that aids sustainable development. OceanTeacher is part of the International Oceanographic Data and Information Exchange (IODE) Programme of the Intergovernmental Oceanographic Commission (IOC) of UNESCO. It has trained nearly 2,000 students from 120 countries since 2005 (https://classroom.oceanteacher.org/mod/page/view.php?id=2033). OTGA has hosted OBIS training workshops to train data providers on how to prepare, standardize, and submit their data to OBIS, where their data is cited and safely secured. Organisations such as OTGA need to be financially supported by governments in order to actively educate and train data keepers and encourage them to share their data with the global community. However, as the scientific community is relatively small and financial sources for training are limited, the future of largescale biodiversity studies is likely to rely on the well-designed application of citizen science in addition to technological advances (Stuart-Smith et al. 2017; Thiel et al. 2014).

\section{Promoting synergy of biodiversity research efforts via increased collaboration at all levels.}

In order to predict and discover biodiversity on a global scale, collaborative approaches among institutions and nations are necessary. Guralnick et al. (2007) proposed a framework to use online databases and tools to improve and standardize geographic data, and to validate and highlight taxonomic data and misidentifications. They also suggested that a global infrastructure for webbased tools would enhance the quality of visualizing and standardizing raw biodiversity data and lead to a higher degree of collaboration and accessibility of knowledge (Guralnick et al. 2007).

The decade long Census of Marine Life was the largest global collaboration amongst marine biologists (O'Dor et al. 2012). Its legacy continues in OBIS with regard to data publication, but also continued international collaboration amongst polar, deep-sea and other researchers. The 
158

159

160

161

162

163

164

165

166

167

168

169

170

171

172

173

174

175

176

177

178

179

180

181

182

183

184

185

186

187

188

189

190

191

192

193

194

195

196

197

International Association for Biological Oceanography (IABO) is the organisation officially responsible for coordinating the marine biodiversity community (Costello et al. 2015a). It runs the MARINE-B email list with over 1,000 subscribers, and holds a World Conference on Marine Biodiversity every three years. Many others, often more specialist-focused, conferences also serve to bring marine biodiversity researchers together. These serve to make introductions and help build collaborative relationships among researchers. However, most research funding is for topics of national rather than international importance. For example, not every country will have specialist expertise in every taxonomic group. Thus, sharing of taxonomic expertise can alleviate funding deficits, allow the transfer of knowledge, and lead to international partnerships.

The number of marine species formally described each year has never been greater, and aside from naming these species, more work is required to understand their life histories and ecology, biogeography, and evolution (Appeltans et al. 2012a; Appeltans et al. 2012b). Costello et al. (2015b) recommended the use of collaborative online databases, taxonomic effort improved and increased through communication, easier access to specimens, engagement of non-specialists, and international collaboration (Costello et al. 2015b). Further, Costello et al. (2013c) advocated abandoning "data-sharing" and instead suggested requiring data publication within a journal or to online infrastructures such as OBIS, WoRMS, and/or the Global Biodiversity Information Facility (GBIF) (Costello et al. 2013c). A fundamental aspect of Aichi Target 19, namely discovering the full extent of biodiversity in the world's oceans, is not possible without international collaboration.

\section{Utilization and promotion of taxonomic expertise and species identification tools to better recognize and catalogue biodiversity.}

"Good" taxonomy is an absolute necessity for biodiversity recognition and management (Thomson et al. 2018). It is very important to pass on the knowledge of experienced taxonomists to others. In this regard, field-specific training workshops can be of great importance. As an example, two 'IceAGE (Icelandic marine Animals: Genetics and Ecology) amphipod identification workshops' were recently held, consisting of two weeks of work of a group of taxonomists accompanied by students. This resulted in the identification of more than 20,000 amphipod specimens, and the publication of seven research papers dealing with the taxonomy, diversity and ecology of this group around Iceland (Brix et al. 2018).

Another problem in recognizing biodiversity is the complexity of access to information and images that can help end-users in identifying the organisms collected in their samples. To solve this requires comprehensive online identification guides to all species on Earth (Costello et al. 2013b). It is surprising that despite the numerous online digital initiatives regarding biodiversity resources for this most practical need (how to identify species) lack leadership and remain scarce. Targeted funding to support such resources is urgently needed to help the wider community identify species quickly and accurately, including species that may be invasive or pathogenic. Despite great publicity and interest, publically available DNA libraries, such as the Barcode of Life (Ratnasingham \& Hebert 2007), are still far from having complete coverage of the Tree of 
198

199

200

201

202

203

204

205

206

207

208

209

210

211

212

213

214

215

216

217

218

219

220

221

222

223

224

225

226

227

228

229

230

231

232

233

234

235

236

237

Life. Moreover, DNA is often only useful if the species has already been formally described, specimens from which DNA has been sampled have been correctly identified, and the DNA sequence(s) published in an open access database. Other tools that can help in species identification for conservation and resource management include interactive keys. Unfortunately, there are only such keys for a few marine taxa, and these mostly concern higher taxonomic levels (family-level or higher) (Dallwitz 2006; Nimbs 2017).

Along with Aichi Target 19, the exchange of knowledge between experienced scientists and young researchers as well as the use of different identification tools (e.g. interactive keys, barcode databases) will help in biodiversity recognition. These targets need to be prioritised by governments and funding agencies as they are fundamental to quality assurance in other areas of biology, ecology, and resource management.

\section{Improvement and standardization of genetic, genomic, and other "omics" tools to aid in discovery, assessment, description, and cataloging of biodiversity.}

Countless studies have used genomic tools to study marine biodiversity, connectivity, and functional diversity (Carvalho et al. 2010). While data sharing, standardized sampling, metadata collection, and sequencing protocols still require significant standardization, the use of repositories such as GenBank, Dryad, and Sequence Read Archive have made published data much more accessible. We expect this trend to continue as new tools, such as the Genomic Observatories Metadata database (GeOMe), streamline sequencing data and metadata submission (Deck et al. 2017).

The classification and phylogeny of eukaryotic organisms benefits from the use of genetic markers that help delineate species in combination with morphological, ecological, and/or physiological information (Hebert et al. 2003). Currently, no uniform threshold value has been established for species delineation, and there is no single "universal" DNA barcode that captures all eukaryotic life. Even within a single animal order there can be large differences in this value between families (Tempestini et al. 2018). Despite these issues, DNA barcoding and nextgeneration metabarcoding can reveal genetic diversity and are useful tools for the description and cataloguing of biodiversity.

Modern high-throughput sequencing (HTS) technologies have advanced DNA barcoding methods by producing millions of individual sequences per analyzed sample, enabling DNA metabarcoding from environmental DNA (eDNA) and complex community mixtures. Community and environmental metabarcoding are both useful tools to discover cryptic (undetected until genetic analyses) diversity in the marine realm, and assess ocean biodiversity in a non-invasive and high-throughput manner (Goodwin et al. 2017).

In order to obtain robust and reproducible metabarcoding results, critical methodological aspects remain to be improved (Dickie et al. 2018; Goldberg et al. 2016; Nichols et al. 2018). Studies are needed to address the effects of alternative protocols on sampling, molecular, and bioinformatic processing level in order to develop standardized and reliable techniques for 
238

239

240

241

242

243

244

245

246

247

248

249

250

251

252

253

254

255

256

257

258

259

260

261

262

263

264

265

266

267

268

269

270

271

272

273

274

275

276

277

applying these new methods. Furthermore, because large amounts of marine organisms have not been genetically characterized, integrative approaches should be supported in order to fill database gaps. The continued improvement and standardization of genetic, genomic, and other "-omics" tools (e.g. proteomics, transcriptomics) will continue to be valuable components in the discovery of new marine prokaryotes and eukaryotes, as well as in monitoring biodiversity, thereby contributing to Aichi Target 19.

\section{Identifying biodiversity and biogeographic knowledge gaps and promoting efforts to reduce such gaps.}

Deep-sea ecosystems include about $65 \%$ of the world's surface but are far less studied and sampled than shallower depths (Costello et al. 2018; Costello et al. 2010). Although deep-sea studies have increased rapidly in recent decades, there are large gaps in global sampling coverage, for example in the Indian and Pacific Oceans, and major efforts are needed to continue to be directed into offshore research (Saeedi et al. 2019). The distribution and diversity of deep-sea fauna thus still remains poorly-known due to the size and remoteness of deep-sea ecosystems. For example, recent studies have shown that the global latitudinal marine species richness gradient follows a bi-modal pattern related to temperature and habitat availability (Chaudhary et al. 2016a; Chaudhary et al. 2017; Saeedi et al. 2017a; Saeedi \& Costello 2019a; Saeedi \& Costello 2019b; Saeedi et al. 2017b). This finding is supported by the fossil record, which shows reduced species richness at the equator in warm periods (Kiessling \& Aberhan 2007). As such, the peaks in this bimodal distribution may become further separated under future climate change and ocean warming. However, there is still no consensus about this bimodal pattern in the deep sea, where food supply may be more important than temperature in defining species distribution. For example, Woolley et al. (2016) examined 165,000 distribution records of Ophiuroidea and revealed that biogeographic patterns in species richness in the deep sea are associated with chemical energy and proximity to slope habitats. However, these patterns require investigation in other taxa, from micro- to mega-fauna, epi-fauna and infauna (Woolley et al. 2016).

One issue in studying present and future global deep-sea biodiversity patterns are the few publicly available distribution records and environmental data. Deep-sea expeditions began over 100 years ago, but distribution data are often still retained in inaccessible archives, sometimes in local languages of that country, and are not publically available to the global community. Additionally, acquisition of data describing the distributions of deep-sea species is often limited by prohibitive costs and logistical difficulties in surveying the deep ocean. Environmental suitability modeling has thus become a cost-effective tool for identifying potential locations of deep-sea species, particularly for areas that have never been explored (Assis et al. 2018; Basher \& Costello 2016; Danovaro et al. 2017; Serrano et al. 2017).

Understanding how abiotic drivers influence species distributions can contribute to filling spatial gaps of biodiversity hotspots and endangered areas (McHenry et al. 2017; Saeedi et al. 2017a; Saeedi \& Costello 2019a; Saeedi \& Costello 2019b; Saeedi et al. 2017b). Since some of 
278 these drivers can be observed by satellite imagery, it is possible to model some community 279 assemblages in difficult-to-access locations. The development of models of species richness and 280 cumulative anthropogenic impact distributions could be useful for conservation purposes and/or 281 other spatial planning applications (Selig et al. 2014). Costello et al. (2018) proposed that sampling 282 of the oceans should be stratified in relation to environmental variability, with more variable 283 environments receiving more sampling focus in space and time (Costello et al. 2018). Coupled 284 with a recent objective (data driven) delineation of marine biodiversity into 30 biogeographic 285 realms based on the endemicities of marine plants and animals (Costello et al. 2018; Costello et 286 al. 2010; Costello et al. 2015b), this provides a framework for more representative sampling of the 287 oceans. These realms include 18 continental-shelf and 12 offshore realms, including unique seas, 288 such as the Baltic and Black seas, and subdivisions of the Indian, Atlantic, and Pacific oceans, and 289 polar waters. These are broad scale patterns, and application of stratified sampling at local levels 290 requires finer spatial resolution data; such as benthic habitat maps and observations of movements 291 of threatened species to know where they occur.

292

\section{Control of anthropogenic pressures on vulnerable ecosystems impacted by climate change or ocean acidification to maintain their integrity and functioning.}

Fisheries and marine mammal hunting have had large impacts on biodiversity at local scales for centuries, and at global scales for the past two centuries (Pauly et al. 2002). Clearly fishery management measures struggle to prevent overfishing, and trawling that destroys seabed habitats is widely permitted, while bycatch of seabirds, turtles and marine mammals is pushing some species to extinction (McCauley et al. 2015). Progress in reducing bycatch is compromising reaching the achievement of Aichi Target 12 related to preventing species extinctions. A proven

303

304 solution to reversing some negative trajectories are marine reserves (no-take MPAs) (Costello 2014). However, about two-thirds of coastal countries lack even one marine reserve, and over $90 \%$ of MPAs allow fishing and thus prevent the recovery of biodiversity to natural conditions (Costello \& Ballantine 2015). This failure to conserve and help fisheries recover, despite the potential benefits of MPAs to nature, education, science (they act as controls for effects of fishing outside them), tourism, and fish populations defies what is best for society. With less than $3 \%$ of the ocean in reserves, there seems little hope that Aichi Target 11's goal of $10 \%$ of the oceans being protected in MPAs by 2020 will be reached. In addition, there appears to be negligible progress towards more sustainable use of the oceans, as called for in Targets 4, 6 and 7. Target 3, the reduction of harmful subsidies, has also seen little progress and too many fisheries still receive indirect and/or direct subsidies from governments that enable further unsustainable overfishing.

Aichi Target 10 calls for reduced anthropogenic impacts on coral reefs. Coral reefs suffered global-scale bleaching events in 2015-2017, even within MPAs, resulting in massive damage to these ecosystems, including mass mortality of hermatypic corals and other zooxanthellate organisms (Hughes et al. 2017), and associated reduced ecosystem functioning (Hughes et al. 2018a; Hughes et al. 2018b). Additionally, such events have economic effects such as reduced 
318 tourism (Prideaux et al. 2017). Overall, the trajectory of coral reefs continues to be one of 319 downward degradation in the face of increasing anthropogenic pressures, including climate change 320 and continued exploitation (Heery et al. 2018).

321

322

323

324

325

326

327

328

329

330

331

332

333

334

335

336

337

338

339

340

341

342

343

344

345

346

347

348

349

350

351

352

353

354

355

356

357

Other anthropogenic impacts on marine biodiversity include excess nutrient input, oxygen depletion, and invasive species. Levels of these impacts are to be reduced and their management improved as part of Aichi Targets 8 and 9. Progress in management of introduced and invasive marine species has been made with the establishment of the World Register of Introduced Marine Species (WRiMS) (Ahyong 2018). Because of the nature of invasive species, management of their information is most cost-effectively done at a global rather than local scale. The next steps should include access to species identification resources and a dynamic online reporting and early warning system.

Both global warming and ocean acidification are closely linked with the anthropogenic input of $\mathrm{CO}_{2}$ and other greenhouse gases into the atmosphere, and without controlling these issues, the future of coral reefs looks bleak (IPCC 2018). Minimizing anthropogenic impacts such as increased runoff from coastal development and reducing overfishing can help delay the degradation of coral reef ecosystems, but it is estimated more than half of all coral reefs now experience medium to high anthropogenic pressures (Halpern et al. 2008) and the extirpation of species from many coral reefs due to climate change is predicted (Molinos et al. 2016).

There are some success stories, such as Palau, which has passed stringent legislation protecting coral reef diversity, including the world's first no-take zone for sharks (Vianna et al. 2012), stringent legal protection (Gouezo et al. 2017), and a visitor's pledge and public awareness campaign (https://palaupledge.com/). Other regions or countries following the lead of these exemplars could help buy time for coral reef ecosystems. For instance, the Australian government implemented the Great Barrier Reef (GBR) Zoning Plan 2003 in 2004, which set aside one-third of the GBR as a no-take zone (McCook et al. 2010). This resulted in a significantly lower proportion of reefs being affected by Crown-of-thorns starfish outbreaks in no-take zones than in fished zones (McCook et al. 2010), but the trajectory of GBR coral reef ecosystems remains bleak due to warming-associated coral bleaching (Hughes et al. 2018a; Hughes et al. 2018b).

\section{Conclusions}

While there has been considerable progress in addressing many of the priorities of the Aichi Targets, including the development and application of biodiversity tools and higher standards, as well as increased educational activity and increasing standardization of genetic and genomic tools, progress towards sustainable use is very limited (Table 1). Of the seven priorities for marine biodiversity to achieve the Achi Targets we reviewed here, we judged six have seen some progress. However, other goals such as reducing anthropogenic stressors on vulnerable ecosystems have clearly not been met and seem certain to fall short of the 2020 Targets, as previously concluded (Tittensor et al. 2014). We recommend continued efforts regarding international cooperation in marine biodiversity informatics to increase efficiencies of data management and accessibility, paralleled by field observations stratified by environmental conditions and societal needs, 
358

359

360

361

362

363

364

365

366

367

368

369

370

371

372

373

374

375

376

377

378

379

380

381

382

383

384

385

386

387

388

389

390

391

392

393

394

395

396

397

398

399

400

401

402

403

404

synergised by online access to taxonomic information and species identification guides, and research into more cost-efficient methods for field sampling that minimise impacts on biodiversity (e.g. sensors, video, eDNA). This surveillance of marine biodiversity should occur in areas where human impacts, particularly fishing, occur, but also in fully-protected Marine Protected Areas where no fishing occurs (i.e., marine reserves). The lack of progress towards establishing the latter reference areas compromises our understanding of natural conditions and how to judge the sustainability of human activities in the ocean and their impacts on marine biodiversity.

\section{Acknowledgements}

We would like to thank David Beauchesne, Rémi M. Daigle, Jésica Goldsmit, Philippe Archambault, Anna Metaxas, and Paul Snelgrove for their thoughts and leadership of the mentorship program organizing committee and workshop facilitators. Special thanks also to Rémi M. Daigle and Jésica Goldsmit for reviewing the current paper. Comments from Martin Thiel and Naomi Kingston greatly improved an earlier version of this paper.

\footnotetext{
References

Ahyong SC, M. J.; Galil, B. S.; Gollasch, S.; Hutchings, P.; Katsanevakis, S.; Lejeusne, C.; Marchini, A.; Occhipinti, A.; Pagad, S.; Poore, G.; Rius, M.; Robinson, T. B.; Sterrer, W.; Turon, X.; Willan, R. C.; Zhan, A. . 2018. World Register of Introduced Marine Species (WRiMS). Available at http://www.marinespecies.org/introduced (accessed 2018-10-14 2018).

Appeltans W, Ahyong ST, Anderson G, Angel MV, Artois T, Bailly N, Bamber R, Barber A, Bartsch I, and Berta A. 2012a. The magnitude of global marine species diversity. Current Biology 22:21892202.

Appeltans W, Bouchet P, Boxshall G, Fauchald K, Gordon D, Hoeksema B, Poore G, Van Soest R, Stöhr $\mathrm{S}$, and Walter T. 2012b. World register of marine species.

Assis J, Tyberghein L, Bosch S, Verbruggen H, Serrão EA, and De Clerck O. 2018. Bio-ORACLE v2.0: Extending marine data layers for bioclimatic modelling. Global Ecology and Biogeography 27:277-284. doi:10.1111/geb.12693

Barroso R, Kudenov JD, Halanych KM, Saeedi H, Sumida PYG, and Bernardino AF. 2018. A new species of xylophylic fireworm (Annelida: Amphinomidae: Cryptonome) from deep-sea wood falls in the SW Atlantic. Deep Sea Research Part I: Oceanographic Research Papers 137:66-75. https://doi.org/10.1016/j.dsr.2018.05.005

Basher Z, and Costello MJ. 2016. The past, present and future distribution of a deep-sea shrimp in the Southern Ocean. Peerj 4. 10.7717/peerj.1713

Brix S, Lörz A-N, Jażdżewska AM, Hughes L, Tandberg AHS, Pabis K, Stransky B, Krapp-Schickel T, Sorbe JC, Hendrycks E, Vader W, Frutos I, Horton T, Jażdżewski K, Peart R, Beermann J, Coleman CO, Buhl-Mortensen L, Corbari L, Havermans C, Tato R, and Jimenez Campean A. 2018. Amphipod family distributions around Iceland. ZooKeys 731:1-53.

Brown JH, and Svenning JC. 2014. Why are there so many species in the tropics? Journal of Biogeography 41:8-22. doi:10.1111/jbi.12228

Carvalho G, Creer S, Allen MJ, Costa F, Tsigenopoulos C, Le Goff-Vitry M, Magoulas A, Medlin L, and Metfies K. 2010. Genomics in the discovery and monitoring of marine biodiversity. Introduction to Marine Genomics: Springer, 1-32.

Chaudhary C, Saeedi H, and Castello MJ. 2016a. Bimodality of Latitudinal Gradients in Marine Species Richness. Trends in Ecology \& Evolution 31:670-676. 10.1016/j.tree.2016.06.001

Chaudhary C, Saeedi H, and Costello MJ. 2016b. Bimodality of Latitudinal Gradients in Marine Species Richness. Trends in Ecology \& Evolution 31:670-676. 10.1016/j.tree.2016.06.001
}

Peer] reviewing PDF | (2019:01:34669:1:1:NEW 4 May 2019) 
405

406

407

408

409

410

411

412

413

414

415

416

417

418

419

420

421

422

423

424

425

426

427

428

429

430

431

432

433

434

435

436

437

438

439

440

441

442

443

444

445

446

447

448

449

450

451

452

453

454

Chaudhary C, Saeedi H, and Costello MJ. 2017. Marine Species Richness Is Bimodal with Latitude: A Reply to Fernandez and Marques. Trends in Ecology \& Evolution 32:234-237. 10.1016/j.tree.2017.02.007

Clarke A, and Gaston KJ. 2006. Climate, energy and diversity. Proceedings Biological sciences 273:2257-2266. 10.1098/rspb.2006.3545

Claus S, De Hauwere N, Vanhoorne B, Deckers P, Souza Dias F, Hernandez F, and Mees J. 2014. Marine regions: towards a global standard for georeferenced marine names and boundaries. Marine Geodesy 37:99-125.

Costello MJ. 2014. Long live Marine Reserves: A review of experiences and benefits. Biological Conservation 176:289-296.

Costello MJ, Archambault P, Chavanich S, Miloslavich P, Paterson DM, Phang S-M, Pinto IS, PierrotBults A, Song S, and Soto EH. 2015a. Organizing, supporting and linking the world marine biodiversity research community. Journal of the Marine Biological Association of the United Kingdom 95:431-433.

Costello MJ, and Ballantine B. 2015. Biodiversity conservation should focus on no-take Marine Reserves: 94\% of Marine Protected Areas allow fishing. Trends in Ecology \& Evolution 30:507-509.

Costello MJ, Basher Z, Sayre R, Breyer S, and Wright DJ. 2018. Stratifying ocean sampling globally and with depth to account for environmental variability. Scientific Reports 8:11259.

Costello MJ, Bouchet P, Boxshall G, Fauchald K, Gordon D, Hoeksema BW, Poore GC, van Soest RW, Stöhr S, and Walter TC. 2013a. Global coordination and standardisation in marine biodiversity through the World Register of Marine Species (WoRMS) and related databases. PLOS ONE $8: \mathrm{e} 51629$.

Costello MJ, and Chaudhary C. 2017a. Marine biodiversity, biogeography, deep-sea gradients, and conservation. Current Biology 27:R511-R527.

Costello MJ, and Chaudhary C. 2017b. Marine Biodiversity, Biogeography, Deep-Sea Gradients, and Conservation. Curr Biol 27:R511-r527. 10.1016/j.cub.2017.04.060

Costello MJ, Cheung A, and De Hauwere N. 2010. Surface Area and the Seabed Area, Volume, Depth, Slope, and Topographic Variation for the World's Seas, Oceans, and Countries. Environmental Science \& Technology 44:8821-8828. 10.1021/es1012752

Costello MJ, May RM, and Stork NE. 2013b. Can we name Earth's species before they go extinct? Science 339:413-416.

Costello MJ, Michener WK, Gahegan M, Zhang Z-Q, and Bourne PE. 2013c. Biodiversity data should be published, cited, and peer reviewed. Trends in Ecology \& Evolution 28:454-461.

Costello MJ, Vanhoorne B, and Appeltans W. 2015b. Conservation of biodiversity through taxonomy, data publication, and collaborative infrastructures. Conservation Biology 29:1094-1099.

Costello MJ, and Wieczorek J. 2014. Best practice for biodiversity data management and publication. Biological Conservation 173:68-73.

Dallwitz M. 2006. Descriptions, illustrations, interactive identification, and information retrieval from DELTA databases. DELTA-Dåscription Language for Taxonomy.

Danovaro R, Corinaldesi C, Dell'Anno A, and Snelgrove PVR. 2017. The deep-sea under global change. Current Biology 27:R461-R465. 10.1016/j.cub.2017.02.046

De Pooter D, Appeltans W, Bailly N, Bristol S, Deneudt K, Eliezer M, Fujioka E, Giorgetti A, Goldstein P, Lewis M, Lipizer M, Mackay K, Marin M, Moncoiffé G, Nikolopoulou S, Provoost P, Rauch S, Roubicek A, Torres C, van de Putte A, Vandepitte L, Vanhoorne B, Vinci M, Wambiji N, Watts D, Klein Salas E, and Hernandez F. 2017. Toward a new data standard for combined marine biological and environmental datasets - expanding OBIS beyond species occurrences. Biodiversity Data Journal 5. 10.3897/BDJ.5.e10989

Deck J, Gaither MR, Ewing R, Bird CE, Davies N, Meyer C, Riginos C, Toonen RJ, and Crandall ED. 2017. The Genomic Observatories Metadatabase (GeOMe): A new repository for field and sampling event metadata associated with genetic samples. PLoS biology 15:e2002925.

PeerJ reviewing PDF | (2019:01:34669:1:1:NEW 4 May 2019) 
455

456

457

458

459

460

461

462

463

464

465

466

467

468

469

470

471

472

473

474

475

476

477

478

479

480

481

482

483

484

485

486

487

488

489

490

491

492

493

494

495

496

497

498

499

500

501

502

503

504

505

Dickie IA, Boyer S, Buckley H, Duncan RP, Gardner P, Hogg ID, Holdaway RJ, Lear G, Makiola A, and Morales SE. 2018. Towards robust and repeatable sampling methods in eDNA based studies. Molecular ecology resources.

Erwin DH. 2009. Climate as a Driver of Evolutionary Change. Current Biology 19:R575-R583. https://doi.org/10.1016/j.cub.2009.05.047

Fernández M, Astorga A, Navarrete SA, Valdovinos C, and Marquet PA. 2009. Deconstructing latitudinal species richness patterns in the ocean: does larval development hold the clue? Ecology Letters 12:601-611. doi:10.1111/j.1461-0248.2009.01315.x

Goldberg CS, Turner CR, Deiner K, Klymus KE, Thomsen PF, Murphy MA, Spear SF, McKee A, Oyler-McCance SJ, and Cornman RS. 2016. Critical considerations for the application of environmental DNA methods to detect aquatic species. Methods in Ecology and Evolution 7:1299-1307.

Goodwin KD, Thompson LR, Duarte B, Kahlke T, Thompson AR, Marques JC, and Caçador I. 2017. DNA sequencing as a tool to monitor marine ecological status. Frontiers in Marine Science 4:107.

Gouezo M, Nestor V, Olsudong D, Marino L, Mereb G, Jonathan R, and Golbuu Y. 2017. 15 years of coral reef monitoring demonstrates the resilience of Palau's coral reefs.

Guralnick RP, Hill AW, and Lane M. 2007. Towards a collaborative, global infrastructure for biodiversity assessment. Ecology Letters 10:663-672.

Halpern BS, Walbridge S, Selkoe KA, Kappel CV, Micheli F, D'agrosa C, Bruno JF, Casey KS, Ebert C, and Fox HE. 2008. A global map of human impact on marine ecosystems. Science 319:948-952.

Hebert PD, Ratnasingham S, and de Waard JR. 2003. Barcoding animal life: cytochrome c oxidase subunit 1 divergences among closely related species. Proceedings of the Royal Society of London B: Biological Sciences 270:S96-S99.

Heery EC, Hoeksema BW, Browne NK, Reimer JD, Ang PO, Huang D, Friess DA, Chou LM, Loke LH, and Saksena-Taylor P. 2018. Urban coral reefs: Degradation and resilience of hard coral assemblages in coastal cities of East and Southeast Asia. Marine Pollution Bulletin 135:654-681.

Helmut Hillebrand. 2004. On the Generality of the Latitudinal Diversity Gradient. The American Naturalist 163:192-211. 10.1086/381004

Hughes T, Kerry J, and Simpson T. 2018a. Large-scale bleaching of corals on the Great Barrier Reef. Ecology 99:501-501.

Hughes TP, Kerry JT, Álvarez-Noriega M, Álvarez-Romero JG, Anderson KD, Baird AH, Babcock RC, Beger M, Bellwood DR, and Berkelmans R. 2017. Global warming and recurrent mass bleaching of corals. Nature 543:373.

Hughes TP, Kerry JT, Baird AH, Connolly SR, Dietzel A, Eakin CM, Heron SF, Hoey AS, Hoogenboom MO, and Liu G. 2018b. Global warming transforms coral reef assemblages. Nature 556:492.

Kiessling W, and Aberhan M. 2007. Geographical distribution and extinction risk: lessons from TriassicJurassic marine benthic organisms. Journal of Biogeography 34:1473-1489. 10.1111/j.13652699.2007.01709.x

McCauley DJ, Pinsky ML, Palumbi SR, Estes JA, Joyce FH, and Warner RR. 2015. Marine defaunation: animal loss in the global ocean. Science 347:1255641.

McCook LJ, Ayling T, Cappo M, Choat JH, Evans RD, De Freitas DM, Heupel M, Hughes TP, Jones GP, and Mapstone B. 2010. Adaptive management of the Great Barrier Reef: a globally significant demonstration of the benefits of networks of marine reserves. Proceedings of the National Academy of Sciences 107:18278-18285.

McHenry J, Steneck RS, and Brady DC. 2017. Abiotic proxies for predictive mapping of nearshore benthic assemblages: implications for marine spatial planning. Ecological Applications 27:603618.

Mittelbach GG, Schemske DW, Cornell HV, Allen AP, Brown JM, Bush MB, Harrison SP, Hurlbert AH, Knowlton N, Lessios HA, McCain CM, McCune AR, McDade LA, McPeek MA, Near TJ, Price TD, Ricklefs RE, Roy K, Sax DF, Schluter D, Sobel JM, and Turelli M. 2007. Evolution and the

Peer] reviewing PDF | (2019:01:34669:1:1:NEW 4 May 2019) 
506

507

508

509

510

511

512

513

514

515

516

517

518

519

520

521

522

523

524

525

526

527

528

529

530

531

532

533

534

535

536

537

538

539

540

541

542

543

544

545

546

547

548

549

550

551

552

553

554

555

556

latitudinal diversity gradient: speciation, extinction and biogeography. Ecology Letters 10:315331. doi:10.1111/j.1461-0248.2007.01020.x

Molinos JG, Halpern BS, Schoeman DS, Brown CJ, Kiessling W, Moore PJ, Pandolfi JM, Poloczanska ES, Richardson AJ, and Burrows MT. 2016. Climate velocity and the future global redistribution of marine biodiversity. Nature Climate Change 6:83.

Nichols RV, Vollmers C, Newsom LA, Wang Y, Heintzman PD, Leighton M, Green RE, and Shapiro B. 2018. Minimizing polymerase biases in metabarcoding. Molecular ecology resources.

Nimbs MJ. 2017. NudiKey: an illustrated, interactive identification key to the families of Australian heterobranch sea-slugs (Mollusca: Gastropoda). Australian Zoologist 38:537-546.

O'Dor R, Boustany AM, Chittenden CM, Costello MJ, Moustahfid H, Payne J, Steinke D, Stokesbury MJ, and Vanden Berghe E. 2012. A census of fishes and everything they eat: How the census of marine life advanced fisheries science. Fisheries 37:398-409.

Palumbi SR. 2003. Population genetics, demographic connectivity, and the design of marine reserves. Ecological Applications 13:146-158.

Pauly D, Christensen V, Guénette S, Pitcher T, Sumaila U, Walters C, Watson R, and Zeller D. 2002. Towards sustainability in world fisheries. Nature418 (6898): 689-695.

Prideaux B, Carmody J, and Pabel A. 2017. Impacts of the 2016 and 2017 mass coral bleaching events on the Great Barrier Reef tourism industry and tourism-dependent coastal communities of Queensland. Report to the Reef and Rainforest Research Centre Limited Cairns: Reef and Rainforest Research Centre Limited.

Provoost P BS. 2018. "robis: R Client to access data from the OBIS API." Ocean Biogeographic Information System. R package version 1.0.1 ed: Intergovernmental Oceanographic Commission of UNESCO.

Ratnasingham S, and Hebert PD. 2007. BOLD: The Barcode of Life Data System (http://www. barcodinglife. org). Molecular ecology notes 7:355-364.

Saeedi H, Basher Z, and Costello MJ. 2016. Modelling present and future global distributions of razor clams (Bivalvia: Solenidae). Helgoland Marine Research 70:23. 10.1186/s10152-016-0477-4

Saeedi H, Basher Z, and Costello MJ. 2017a. Modelling present and future global distributions of razor clams (Bivalvia: Solenidae). Helgoland Marine Research 70:23.

Saeedi H, Bernardino AF, Shimabukuro M, Falchetto G, and Sumida PYG. 2019. Macrofaunal community structure and biodiversity patterns based on a wood-fall experiment in the deep South-west Atlantic. Deep Sea Research Part I: Oceanographic Research Papers. https://doi.org/10.1016/j.dsr.2019.01.008

Saeedi H, and Costello MJ. 2019a. The Biology, Ecology, and Societal Importance of Razor Clams. Reference Module in Earth Systems and Environmental Sciences: Elsevier.

Saeedi H, and Costello MJ. 2019b. A world dataset on the geographic distributions of Solenidae razor clams (Mollusca: Bivalvia). Biodiversity Data Journal 7. 10.3897/BDJ.7.e31375

Saeedi H, Dennis TE, and Costello MJ. 2017b. Bimodal latitudinal species richness and high endemicity of razor clams (Mollusca). Journal of Biogeography 44:592-604. doi:10.1111/jbi.12903

Saeedi H, Dennis, T. E., Costello, M. J. 2017. Bimodal latitudinal species richness and high endemicity of razor clams (Mollusca). Journal of Biogeography 44:592-604. doi:10.1111/jbi.12903

Selig ER, Turner WR, Troeng S, Wallace BP, Halpern BS, Kaschner K, Lascelles BG, Carpenter KE, and Mittermeier RA. 2014. Global Priorities for Marine Biodiversity Conservation. PLOS ONE 9. 10.1371/journal.pone.0082898

Serrano A, González-Irusta JM, Punzón A, García-Alegre A, Lourido A, Ríos P, Blanco M, GómezBallesteros M, Druet M, Cristobo J, and Cartes JE. 2017. Deep-sea benthic habitats modeling and mapping in a NE Atlantic seamount (Galicia Bank). Deep Sea Research Part I: Oceanographic Research Papers 126:115-127. https://doi.org/10.1016/j.dsr.2017.06.003

Shepherd E, Milner-Gulland EJ, Knight AT, Ling MA, Darrah S, van Soesbergen A, and Burgess ND. 2016. Status and Trends in Global Ecosystem Services and Natural Capital: Assessing Progress Toward Aichi Biodiversity Target 14. Conservation Letters 9:429-437. 10.1111/conl.12320

Peer] reviewing PDF | (2019:01:34669:1:1:NEW 4 May 2019) 
557

558

559

560

561

562

563

564

565

566

567

568

569

570

571

572

573

574

575

576

577

578

579

580

581

582

583

584

585

586

587

588

589

590

591

592

593

594

595

596

597

Stuart-Smith RD, Edgar GJ, Barrett NS, Bates AE, Baker SC, Bax NJ, Becerro MA, Berkhout J, Blanchard JL, and Brock DJ. 2017. Assessing national biodiversity trends for rocky and coral reefs through the integration of citizen science and scientific monitoring programs. Bioscience 67:134-146.

Tempestini A, Rysgaard S, and Dufresne F. 2018. Species identification and connectivity of marine amphipods in Canada's three oceans. PLOS ONE 13:e0197174.

Thiel M, Penna-Díaz MA, Luna-Jorquera G, Salas S, Sellanes J, and Stotz W. 2014. Citizen scientists and marine research: volunteer participants, their contributions, and projection for the future. Oceanography and Marine Biology: An Annual Review 52:257-314.

Thomson SA, Pyle RL, Ahyong ST, Alonso-Zarazaga M, Ammirati J, Araya JF, Ascher JS, Audisio TL, Azevedo-Santos VM, and Bailly N. 2018. Taxonomy based on science is necessary for global conservation. PLoS biology 16:e2005075.

Tittensor DP, Mora C, Jetz W, Lotze HK, Ricard D, Berghe EV, and Worm B. 2010. Global patterns and predictors of marine biodiversity across taxa. Nature 466:1098. 10.1038/nature09329

https:/www.nature.com/articles/nature09329\#supplementary-information

Tittensor DP, Walpole M, Hill SLL, Boyce DG, Britten GL, Burgess ND, Butchart SHM, Leadley PW, Regan EC, Alkemade R, Baumung R, Bellard C, Bouwman L, Bowles-Newark NJ, Chenery AM, Cheung WWL, Christensen V, Cooper HD, Crowther AR, Dixon MJR, Galli A, Gaveau V, Gregory RD, Gutierrez NL, Hirsch TL, Höft R, Januchowski-Hartley SR, Karmann M, Krug CB, Leverington FJ, Loh J, Lojenga RK, Malsch K, Marques A, Morgan DHW, Mumby PJ, Newbold T, Noonan-Mooney K, Pagad SN, Parks BC, Pereira HM, Robertson T, Rondinini C, Santini L, Scharlemann JPW, Schindler S, Sumaila UR, Teh LSL, van Kolck J, Visconti P, and Ye Y. 2014. A mid-term analysis of progress toward international biodiversity targets. Science 346:241-244. $10.1126 /$ science. 1257484

Tomašových A, Jablonski D, Berke SK, Krug AZ, and Valentine JW. 2015. Nonlinear thermal gradients shape broad-scale patterns in geographic range size and can reverse Rapoport's rule. Global Ecology and Biogeography 24:157-167. doi:10.1111/geb.12242

Valentine JW, Jablonski D, and Crame A. 2015. A twofold role for global energy gradients in marine biodiversity trends. Journal of Biogeography 42:997-1005. doi:10.1111/jbi.12515

Vianna G, Meekan M, Pannell D, Marsh S, and Meeuwig J. 2012. Socio-economic value and community benefits from shark-diving tourism in Palau: a sustainable use of reef shark populations. Biological Conservation 145:267-277.

Woolley SNC, Tittensor DP, Dunstan PK, Guillera-Arroita G, Lahoz-Monfort JJ, Wintle BA, Worm B, and O'Hara TD. 2016. Deep-sea diversity patterns are shaped by energy availability. Nature 533:393-+. 10.1038/nature17937

WoRMS. 2018. World Register of Marine Species. Available at http://www. marinespecies.org/aphia.php? $p=$ stats2018).

Yasuhara M, Hunt G, Dowsett HJ, Robinson MM, and Stoll DK. 2012. Latitudinal species diversity gradient of marine zooplankton for the last three million years. Ecology Letters 15:1174-1179. 10.1111/j.1461-0248.2012.01828.x

Peer] reviewing PDF | (2019:01:34669:1:1:NEW 4 May 2019) 


\section{Table $\mathbf{1}$ (on next page)}

The examined Aichi Targets

Table 1. The Aichi Targets examined in this study and their relationship to the scientific priorities identified by participants of the 2018 World Conference on Marine Biodiversity. The Targets were grouped into Strategic Goals by the Convention on Biological Diversity. * negligible progress, ${ }^{* *}$ notable progress, ${ }^{* * *}$ good progress. 


\begin{tabular}{|c|c|c|}
\hline Aichi Target & Scientific Priority & Progress \\
\hline & $\begin{array}{l}\text { Developing, improving and } \\
\text { enhancing biodiversity data } \\
\text { standards, exchange, and analytical } \\
\text { tools, via standardized techniques. } \\
\text { Educational activities to increase } \\
\text { data mobilisation by taxonomists, } \\
\text { data users, and/or wider audiences. }\end{array}$ & $* * *$ \\
\hline $\begin{array}{l}\text { Strategic Goal E: Enhance implementation through } \\
\text { participatory planning, knowledge management and capacity }\end{array}$ & $\begin{array}{l}\text { Promoting synergy of biodiversity } \\
\text { research efforts via increased } \\
\text { collaboration at all levels. }\end{array}$ & $* * *$ \\
\hline \multirow{3}{*}{$\begin{array}{l}\text { Target } 19 \\
\text { By } 2020, \text { knowledge, the science base and technologies relating } \\
\text { to biodiversity, its values, functioning, status and trends, and the } \\
\text { consequences of its loss, are improved, widely shared and } \\
\text { transferred, and applied. }\end{array}$} & $\begin{array}{l}\text { Utilization and promotion of } \\
\text { taxonomic expertise and species } \\
\text { identification tools to better } \\
\text { recognize and catalogue } \\
\text { biodiversity. }\end{array}$ & $* *$ \\
\hline & $\begin{array}{l}\text { Improvement and standardization } \\
\text { of genetic, genomic, and other } \\
\text { "omics" tools to aid in discovery, } \\
\text { assessment, description, and } \\
\text { cataloging of biodiversity. }\end{array}$ & $* *$ \\
\hline & $\begin{array}{l}\text { Identifying biodiversity and } \\
\text { biogeographic knowledge gaps and } \\
\text { promoting efforts to reduce such } \\
\text { gaps. }\end{array}$ & $* * *$ \\
\hline $\begin{array}{l}\text { Strategic Goals A: Address the underlying causes of biodiversity } \\
\text { loss by mainstreaming biodiversity across government and } \\
\text { society [1] B: Reduce the direct pressures on biodiversity and } \\
\text { promote sustainable use, Targets } 6 \text { to } 10 \text { [2] and C: To improve } \\
\text { the status of biodiversity by safeguarding ecosystems, species } \\
\text { and genetic diversity, Targets } 11-13 \text { [3] }\end{array}$ & $\begin{array}{l}\text { Control of anthropogenic pressures } \\
\text { on vulnerable ecosystems impacted } \\
\text { by climate change or ocean } \\
\text { acidification to maintain their } \\
\text { integrity and functioning. }\end{array}$ & $*$ \\
\hline
\end{tabular}

[1] Target 3: By 2020, at the latest, incentives, including subsidies, harmful to biodiversity are eliminated, phased out or reformed in order to minimize or avoid negative impacts, and positive incentives for the conservation and sustainable use of biodiversity are developed and applied, consistent and in harmony with the Convention and other relevant international obligations, taking into account national socio economic conditions. Target 4: By 2020, at the latest, Governments, business and stakeholders at all levels have taken steps to achieve or have implemented plans for sustainable production and consumption and have kept the impacts of use of natural resources well within safe ecological limits.

10 [2] Target 6: By 2020 all fish and invertebrate stocks and aquatic plants are managed and harvested sustainably, legally and applying ecosystem-based approaches, so that overfishing is avoided, recovery plans and measures are in place for all depleted species, fisheries have no significant adverse impacts on threatened species and vulnerable ecosystems and the impacts of fisheries on stocks, species and ecosystems are within safe ecological limits. Target 7: By 2020 areas under agriculture, aquaculture and forestry are managed sustainably, ensuring conservation of biodiversity. Target 8: By 2020, pollution, including from excess nutrients, has been brought to levels that are not detrimental to ecosystem function and biodiversity. Target 9: By 2020, invasive alien species and pathways are identified and prioritized, priority species are controlled or eradicated, and measures are in place to manage 
18 pathways to prevent their introduction and establishment. Target 10: By 2015, the multiple anthropogenic pressures

19 on coral reefs, and other vulnerable ecosystems impacted by climate change or ocean acidification are minimized, so 20 as to maintain their integrity and functioning.

21 [3] Target 11: By 2020, at least 17 per cent of terrestrial and inland water, and 10 per cent of coastal and marine 22 areas, especially areas of particular importance for biodiversity and ecosystem services, are conserved through 23 effectively and equitably managed, ecologically representative and well-connected systems of protected areas and 24 other effective area-based conservation measures and integrated into the wider landscapes and seascapes. Target 12: 25 By 2020 the extinction of known threatened species has been prevented and their conservation status, particularly of 26 those most in decline, has been improved and sustained. Target 13: By 2020, the genetic diversity of cultivated 27 plants and farmed and domesticated animals and of wild relatives, including other socio-economically as well as 28 culturally valuable species, is maintained, and strategies have been developed and implemented for minimizing genetic erosion and safeguarding their genetic diversity. 
Figure 1

Biodiversity data processing

Figure 1. Biodiversity data processing using novel analytical standardized techniques and technologies.

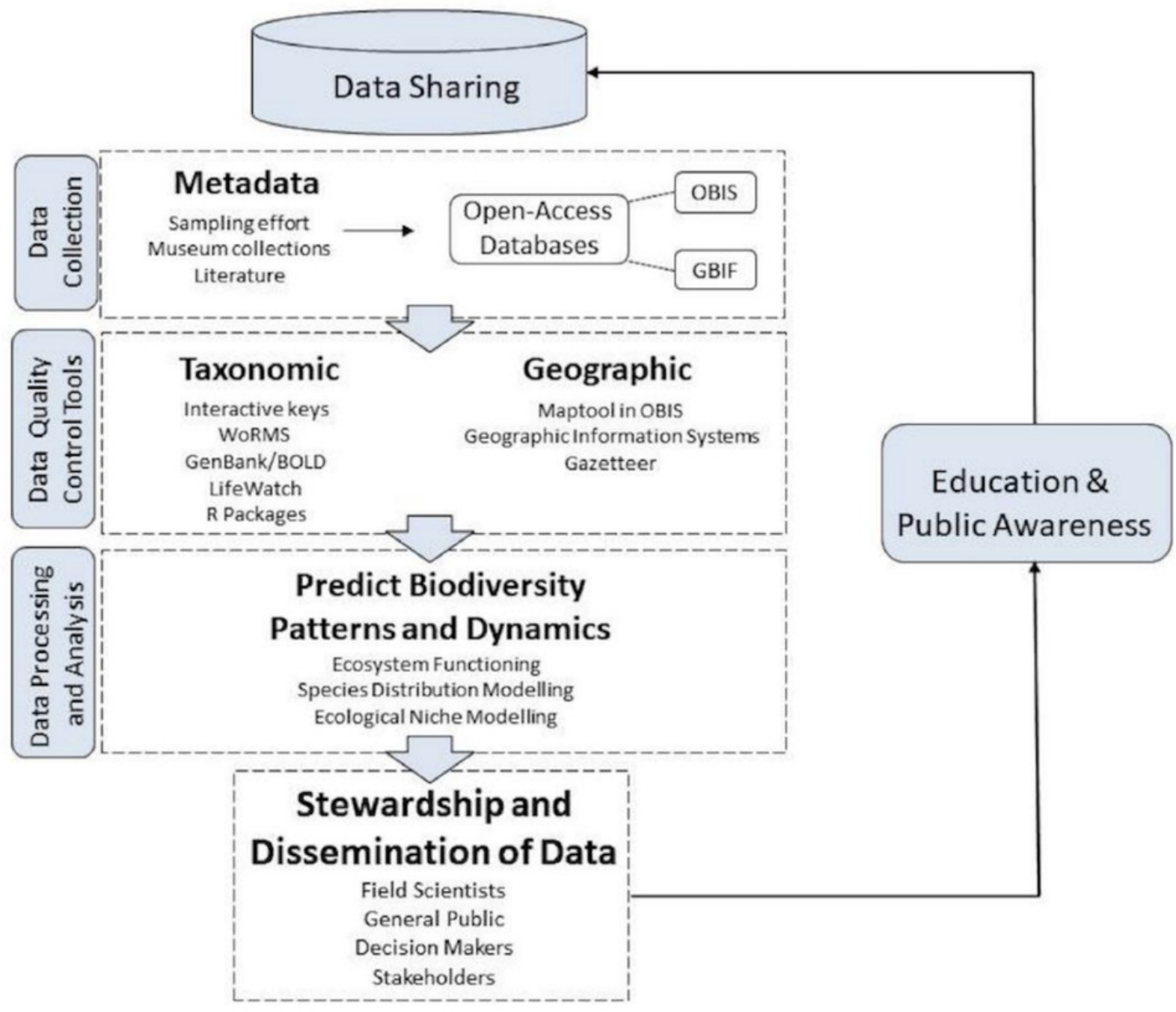

